\title{
Living Anonymity: Exile as Motif in Lenrie Peters' He Walks Alone
}

\author{
Christopher Babatunde Ogunyemi \\ Department of English \\ Joseph Ayo Babalola University, Nigeria. \\ E-mail: bbcoguns2@yahoo.se \\ Niyi Akingbe, $\mathrm{PhD}$ \\ Department of English \\ Joseph Ayo Babalola University \\ Ikeji Arakeji, Nigeria \\ E-mail: deniakingbe@yahoo.com \\ Adebola Abosede Otemuyiwa \\ Department of English \\ Joseph Ayo Babalola University \\ Ikeji Arakeji, Nigeria \\ E-mail: otemuyiwa2011@yahoo.com
}

Received: 27-12- 2012

Accepted: 30-01- 2013

Published: 01-03- 2013

doi:10.7575/aiac.ijalel.v.2n.2p.204

URL: http://dx.doi.org/10.7575/aiac.ijalel.v.2n.2p.204

\begin{abstract}
Exile is strangely compelling to think about but terrible to experience. It is the unhealable rift forced between a human being and a native place, between the self and its true home: its essential sadness can never be surmounted. And while it is true that literature and history contain heroic romantic, glorious, even triumphant episodes in an exile's life, these are no more than efforts meant to overcome the achievements of exile permanently undermined by the loss of something left behind for ever. (Edward Said, 2001:137)
\end{abstract}

Keywords: Living Anonymity, Exile, He Walks Alone and Lenrie Peters

\section{Introduction}

Edward Said's submission above best explains the fundamentals about writings on Exile which portends either selfidentity or collective identity of a group of people who live in a continuum. This kind of writing either informs, educates or entertains but the major motif here is to criticize and to sarcastically inform the people within the literary ethos about the exigency of exile, its psychological effects, sociological effects and even its political effects on African people. Exile writing visualizes issues that bother on alienation and the quest for freedom. Writers throughout the ages have been using their literary works of arts to show various reactions that bother with exile. Some x-ray physical exile others psychological exile which grossly affects the psyche of the writer or the character in question.

Migration and forced migration are panacea to alienation and exile. Writings emanating from such feelings are nostalgic and thought provoking. Many writers have used their works to buttress the feelings of exile in time and space. The experience of exile literature in Lithuania is predicated on the apocalyptic second coming of the soviet armies in Lithuania. This threw away many intellectual and professional away into exile. Poets arose to react critically to these plights. Examples of such poets are Kazys Bradunas (b.1917), Jonas Mekas (b.1922), Algirdas Landsbergs (b.1924) among others from all parts of the world. Our concern in this paper is to examine exile as motif in Lenrie Peters' poetry that is entitled "He Walks Alone" The poem explains various reasons Africans go on exile and their impressions when they feel nostalgic. Feelings for their roots, their families and their cultures give rise to some sensitive impressions in their works of arts. However, the work uses textual analysis to explain how Lenrie Peters uses irony and metaphor to portray the image of exile politically, psychologically, economically and physically as recurring motifs in his poetry. His wealth of imagery is situated within the axis of literary application in order to explain what informs migration literature in Africa. This paper is visualized in six movements: the first being the introduction throws a searchlight into the concept of migration and its attendant example in Lithuania and Africa. The second probes into what constitutes the textual analysis approach; the third views exile as motif in African poetry; the fourth delves into Lenrie Peters' preoccupation of exile; the fifth movement conceptualises the application of the textual analysis to the poem in question and the sixth, being the last movement concludes the work. The paper conceptualises the textual analysis approach to demonstrate the intrinsic value of migration and exile in the body of the text. Daniel Chandler has done some excellent 
application of the textual approach to the mass media. This approach allows concrete insight into the understanding of poetry as it moves in time and space.

\title{
2. Exile as Motif in African Poetry
}

Poetry usually employs "the use of epigrammatic statements, lyrics, concrete images which graphically delineate incontrovertible truths in life and social justice" (Maduka and Eyoh, 2000:14). Based on this, poets such as Williams Wordsworth, John Keats, Shakespeare, Yeats etc use their poetry to explicate various motifs from innocence to experience, nature and love, unbridled quest for social justice and so on. Exile is an example of such subject matter that poetry axiomatically lends its credence on because it deployed terse words and encoded metaphor in the illumination of thematic preoccupation. Poets could successfully communicate their feelings without been harmed or without been intimidated by the societal framework or instrument of power that lacks literary imagination. Similarly, poets easily call the attention of audience to the plight of exile in order to bring about new life and new experiences. It boils down to what is exile.

According to Jacqueline Corness in a paper entitled Alienation and Freedom- A study of Dostoevsky's Notes From Underground as it relates to the Theme of Exile, she defines exile from the perspective of Said when she opines that:

\author{
Exile is not, after all, a matter of choice: you are born into it, \\ or it happens to you. For this reason, exile is often thought to be the \\ most psychological difficult state of removal from, for example, \\ one's country. While some people are separated from \\ their homeland because they have freely chosen to live \\ elsewhere, exiles are considered to be at mercy of external \\ forces (2).
}

Exile is a serious human condition that makes many poets to show their concern and also demonstrate how they feel. Wole Soyinka's "Telephone Conversation" is a capsule presentation of psychological exile experienced in England when he was refused an accommodation simply because he is a black man. Arthur Nortje`s "Autopsy" is a poem that visualises the evil effects of exile on children who were naturally born into it, they feel isolated and perverted. Buhadur Tejani`s "Leaving the Country" is a poem in Africa that showcases the evils behind political exile and alienation. The spirit of nothingness, hollow expectations and practical dislocations are the feelings that emanate from people. African poets reflect exile situation as motif in their poetic canon.

\section{Lenrie Peters and Exile Preoccupations in Poetry}

Although, Lenrie Peters is not a victim of political exile, his exile motif in poetry is predicated on the psychological exile and alienation he experiences in Britain. The same feelings Soyinka experiences which makes him to write the "Telephone Conversation" Before 1965, Peters studies and lives in Cambridge, after the independence of Gambia his country, he came home to help restructure the political and economic situation. His poem "He Walks Alone" is a typical example of exile and alienation people suffer in foreign land. His biography shows that: "He Walks Alone" is a poem that shows degree of alienation African students suffer in Europe. As a result of this alienation in their system, they feel exiled and Peters asks them to go home. The poem is a rich experience from the poet who having studied abroad is critical of the hypocritical behaviours which is sometimes found in Europe. An African student is given quality education but refused employment by the system that educates him. The poem is sarcastic because it tries to ridicule the harsh weather and the harsh behaviours Africans face in diaspora. As a result of alienation, some Africans have lost their roots. They want to behave like the Europeans but it is not possible because their physiological traits were not tailored towards the European individualism. Africans are collective in nature, so when they demonstrate Eurocentric feelings, the Europeans could not accept them, the Africans quickly run back home in order to eat in unison, speak in one accord, love themselves and struggle together in African communalism.

\section{Exile in 'He Walks Alone'}

The poem is written in seven stanzas of unequal five lines. The poet addresses exile as motif because man is an integral factor in society- Exile has caused many untold pain, isolation and rejection. The first stanza reports:

\author{
He walks alone \\ head bowed with memories \\ Exiled in the park \\ some playful thing of long ago \\ glues him to a shop window
}


The poet creates an image of an African man in Europe who is looking for an identity. He is not accepted into the system though he is a legal resident. He cannot vote and be voted for; he cannot seek employment in choice places. He walks alone thinking about home, thinking about his family. Most times he goes around with his head bowed to the colour and psychological differences that exist between him and his host community. At the park, he is always given some distance as if he is a mini-human. The situation on the train is the worst, nobody sits beside him. He feels exiled and alienated. The choice of words here shows that Lenrie Peter employs some coded meanings with words like "head bowed in memories". The exile is confronted by a denial by the host community's culture. But also there is a feeling of belonging to a different but alien culture that has no recognition, and which does not accord him any relevance in the colonial metropolis of London. Hence, his "'head is bowed with memories" and longing for African warmth usually underscored by: communal gathering, scores of festivals, the warmth of comradeship and shared labour, joy of harvest and a recollection of the sparkling African blue weather of the dry season. An underlining feature of the exile's flirtation with memory is his concern for warmth and tenderness sufficiently present in Africa, a memory which unobtrusively can not be obliterated by a stretch of distance from Africa.

In the second stanza, the issue of exile seems more manifest

$$
\begin{aligned}
& \text { Faded suit sharp lined } \\
& \text { loosely held by his proud heart } \\
& \text { shoes scaled with polish } \\
& \text { cannot comprehend; too much } \\
& \text { to tell of harsh experiences }
\end{aligned}
$$

The African tries to emulate the European but he cannot really fit into the system. The exile's consciousness is sharpened against the backdrop of the drudgery of everyday life in London, reverberated by "faded suit", "shoes scaled with polish" which betrays an instalmental living on the fringes of English society. This is a description placed at the disposal of an exceptional sincerity and a compelling purpose of coping with the debilitating English weather. The choice of being cladded in faded suit and a pair of shoes scaled with polish is bewildering to the exile. But how is the exile in English society expected to cope with isolation, harsh weather and cultural shock? How is he to describe and set his experiences within an historical condition which can only be understood by himself? The exile realises that only memory can be employed as a weapon of liberation to break through the walls of isolation and racial discrimination ineluctably grounded in English social milieu. Memory constitutes a bastion of recollection of negative experiences for the exile in the poem. The applications of concrete images such as "proud heart" "shoes scaled with polish" are contrasting. As an immigrant he is proud to have journeyed to other part of the world, but in the end cannot fit into the new environment. Irony is another instrument the poet uses to make his poem satiric in nature.

In this poem, many of these ironies are applicable. The most important are: irony of situation, irony of life, dramatic irony, irony of circumstances and irony of character. This is because exile explores all these feelings in the life of the African whose character is very critical in the poem. Stanzas three and four explain more:

$$
\begin{aligned}
& \text { No coward he } \\
& \text { respository of rejected talents } \\
& \text { an ounce of earth } \\
& \text { silted weightily in his heart. } \\
& \text { the breaking point is looking back }
\end{aligned}
$$

In this stanza, Peters commences a poetic evaluation of the significance of western education to contemporary African students. Inspite of the difficulties generated by the racially stratified England, the persona does not disintegrate with the threats of racism. But has to maintain a stoical fidelity to his pursuit of western education, whose immense reward will translate to the transformation of his African society. And more so, he can not afford to pack his bags and return to Africa, because "'the breaking point is looking back'. But has to cope with the social, psychological and economic stress of England as to acquire western education at all cost. This necessitates that he deplores courage as a tool of postmodernist sensibility, towards surmounting these travails. The treatment of a sensitive socio-political issue of racism in this poem underscores James Reeves's observation that, 'what poetry does to the mass of ordinary experience is to make permanent and memorable whatever in it is vital and significant'(88). Peters in this poem ostensibly criticises racial discrimination, and amplifies the plight of African students in their determination to confront this social malaise.

\author{
Crossed the Rubicon
}

Race, nationality, ideology, religion

arrowed from earth to moon

founder of a new brotherhood

an hero he not of our nation born 
Here, the character in the poem is undergoing some rejections. He is grossly isolated, "crossing the Rubicon" is a metaphor for Atlantic Ocean. The poet is calling an attention that this character who flew across the Atlantic is now been exiled physically and psychologically. He battles racism, nationality stratification resulting into modern slavery, religious differences, ideological divergences, post-nationalism and globalization. Language to this poem is very crucial to the understanding of exile and its attendant evils.

The poet chooses both the connotative and denotative language to portray the colourful images and metaphors which he explores in the handling of exile as motif in the poem" He Walks Alone" Stanzas five, six and seven substantiate this assertion.

\author{
Known no tenderness \\ skin a mosaic of scars \\ heart in fixed deposit \\ safe from ridicule, decomposing \\ Marionette-strings linked with stars
}

Exile go home

under your bed a bowl of tears

leave back streets

nightmares evenings kneeling in pews

brassy noises of homely fires

Dream and wait

coarse cauctus of desert wastes

perhaps tomorrow

sunflowers fading in the heat

will lie insensate at your feet

In this poem, the choice of both connotative language and denotative language is to present the motif of exile in its natural state. The poet wants to prevent ambiguity by using "everyday's language" as connotative and "implied language" as denotative. The image of poverty is too conspicuous in the poem. The character lives in isolated area, some areas are exclusively reserved for immigrants and some jobs are also exclusively reserved for immigrants. Such jobs include cleaning, flushing of toilets, etc. Lenrie Peters is extremely critical about the use of language in the poem. Although he sounds very harsh, maverick and mechanical when he says "exile go home". The poet seems to be worried about frustrations, psychological intimidation people in exile go through. Although this is self exile, he admonishes the Africans that they should seriously start thinking about home for the sake of development and posterity.

Similarly, the arrays of metaphors which are situational make the motif of exile interesting to study. Though exile is a social factor, the poet is calling attention that instead of constant endurance and travails, affected persons can make it good at home. Although man is powerless in the face of uncontrollable phenomenon, the poet achieves success in his artistic craft and the handling of the theme of exile as motif in "He Walks Alone"

The title of the poem is symbolic because it expresses the exile experience and it emphasises individualism which is not part of African culture and tradition. Above all, it is a contribution to African literature because "African literature, indeed the literature of black civilization, in modern times, has moved from the literature of protest to the literature of assertion and emancipation, which also indicates self-examination" (Black Aesthetics, ix). Of paramount significance is the musical theatricality which the poem employs with distinct end rhymes which gives the poem a regular patterning. The significance of this regular patterning is to show that exile is a continuous phenomenon in the life of people. As African people move from one place to the other, other people too may consider relocation from one locale to the other. They would begin to consider balancing with the socio-geographical factor of the environment they find themselves in. In the course of this, nostalgia, pain, acceptance problem sails in. The end rhyme employed by Lenrie Peters could be considered original because it neither conforms to Elizabethan nor the English type.

The tone of the poem is melancholic. That is the situation exile encourages. The poet is exhibiting a practical manifestation of what it is to be in exile. The expectations are usually very high but the system is not accommodating to satisfy all the yearnings revolving in the mind. The audience would perceive "He Walks Alone" as a didactic poem. A didactic poem is a poem that teaches and explains the rudiments about human society and predicament. The motif of exile is an over- riding factor in this poem.

\title{
5. Conclusion
}

The motif of exile is the main preoccupation that Lenrie Peters examines in exhaustive chunk. He uses rich imagery to demonstrate this, bearing in mind that Africans are people of "historical evolution" in the word of Boyin Svetlana. This 
poem is very sensitive to the plight of exile and identity. The use of ordinary language is to denote clear image of understanding so that the issue of ambiguity would not arise. To sum up, Lenrie Peters' "He Walks Alone" is an exemplification of exile experience coupled with the question of identity and how these factors have dire consequences on the people. The rich artistic creation is a contribution to African literature.

\section{References}

Corness, J. (2005): Alienation and Freedom: A Study of Dostoevsky's Notes from Underground as it relates to the Theme of exile. A paper presented at Literature and Exile Seminar, Högskolan Dalarna, Sweden.Spring.

Emenyonu, E. (1990): Literature and Black Aesthetics. Ibadan: Heinemann Nigeria

http://culturalpolitics.net/popular_culture/textual_analysis.

Maduka, C. T. (1999): The Intellectual and The Power Structure. University of Port Harcourt and Ahmadu Bello University Press.

Maduka Chidi. T., \& Luke, E. (2000): Fundamentals of Poetry.Uyo: Scholars Press.

Merkl, D. (2009): The Analysis Methodologies in Corporate Narrative Reporting Research. Gwynedd: Bangor Business Press.

Peters, L. (1999):"He Walks Alone” Poems of Black Africa. Wole Soyinka ed. London: Heinemann

Peters L. (2000): Biography XVII International Poetry Modelling. New York.

Reeves, J. (1958): Teaching Poetry.London: Heinemann.

Said, W E. (2001):Reflections on Exile and other Essays. Cambridge Mass: Harvard University Press.

Silbajors, R. (1972): “The Experience of Exile in Lithuanian Literature”. Ohio State University Lithuanian Quarterly Journal of Arts and Sciences. Antanas Kilmas ed. Volume 18, no.1 Spring. 